\title{
Effect of Prehabilitation Exercise Using Resistance Bands on Quality of Life in Patients Undergoing Total Knee Replacement
}

\author{
Juwita Kusumadewi, Robby Tjandra, Erna Setiawati
}

Department of Physical Medicine and Rehabilitation, Diponegoro University, Semarang, Indonesia

\begin{abstract}
Introduction: An exercise program like prehabilitation exercise is expected to contribute in improving outcomes in Osteoarthritis (OA) postoperatively such as Total Knee Replacement (TKR). Elastic resistance products in prehabilitation exercise programs have been widely used in rehabilitation and are an effective method. Resistance band is one of elastic resistance products that have several advantages. The purpose of this study was to determine the effect of prehabilitation exercise intervention with a resistance band on the quality of life of patients undergoing TKR using the SF-36 questionnaire.

Methods: This study was a randomized controlled trial pre-test and post-test control group design knowing the effects of prehabilitation exercise in patients underwent TKR. 16 subjects were allocated to treatment group $(\mathrm{n}=8)$ which received additional prehabilitation exercise using resistance band and control group $(\mathrm{n}=8)$ with conventional therapy (ergocycle and Transcutaneous Electrical Nerve Stimulation (TENS)) preoperatively. Quality of life assessment using SF-36 score was carried out 4 weeks preoperatively and 8 weeks postoperatively.

Results: The mean baseline value of SF-36 in the treatment group is $41.18 \pm 9.40$ and control group with mean $43.78 \pm 5.66$, did not differ significantly with $\mathrm{p}>0.05$. Both groups experienced a significant increase in their SF-36 post-test scores for the control group $(\mathrm{p}<0.05)$ and the treatment group $(\mathrm{p}<0.05)$. Comparison between groups showed a significant difference $(\mathrm{p}<0.05)$ between the pretest and posttest SF-36 scores where the control group (6.32 \pm 3.21$)$ and treatment group (23.95 \pm 9.75$)$.

Discussion: The SF-36 pre-test score between groups showed no significant difference. While the posttest results had significantly increased in SF-36 mean score in both groups. This might be caused by although the exercises performed by the two groups were different, they still did exercises that had an effect on joints. Despite of that, treatment group post-test results still had significantly better improvement than those of the control group.

Conclusion: Prehabilitation exercise intervention using resistance bands improving the quality of life of patients undergoing TKR. The quality of life improving more in those who do prehabilitation exercise than those who do conventional therapy.
\end{abstract}

Keywords: Prehabilitation exercise, quality of life, total knee replacement. 


\title{
Efek Prehabilitation Exercise dengan Resistance Band terhadap Kualitas Hidup Pasien yang Menjalani Total Knee Replacement
}

\author{
Juwita Kusumadewi, Robby Tjandra, Erna Setiawati
}

rogram Studi Ilmu Kedokteran Fisik dan Rehabilitasi, Universitas Diponegoro, Semarang, Indonesia

\begin{abstract}
ABSTRAK
Pendahuluan: Program latihan seperti prehabilitation exercise diharapkan dapat memberikan kontribusi dalam meningkatkan hasil pasca operasi pada Osteoarthritis (OA) seperti Total Knee Replacement (TKR). Produk elastic resistance dalam program prehabilitation exercise telah banyak digunakan dalam rehabilitasi dan merupakan metode yang efektif. Resistance band merupakan salah satu produk elastic resistance yang memiliki banyak manfaat. Tujuan penelitian ini adalah untuk mengetahui pengaruh intervensi prehabilitation exercise dengan resistance band terhadap kualitas hidup pasien yang menjalani TKR dengan menggunakan kuesioner SF-36.
\end{abstract}

Metode: Penelitian ini merupakan uji coba terkontrol acak pre-test dan post-test control group design untuk mengetahui pengaruh prehabilitation exercise pada pasien yang menjalani TKR. 16 subjek dialokasikan ke kelompok perlakuan $(n=8)$ yang mendapat prehabilitation exercise tambahan menggunakan resistance band dan kelompok kontrol $(n=8)$ dengan terapi konvensional (ergocycle dan Transcutaneous Electrical Nerve Stimulation (TENS)) praoperasi. Penilaian kualitas hidup dengan skor SF-36 dilakukan 4 minggu sebelum operasi dan 8 minggu pascaoperasi.

Hasil: Nilai rerata SF-36 pada kelompok perlakuan adalah 41,18 $\pm 9,40$ dan kelompok kontrol dengan rerata $43,78 \pm 5,66$ tidak signifikan berbeda dengan nilai $p>0,05$. Kedua kelompok mengalami peningkatan yang signifikan pada skor post-test SF-36 dimana kelompok kontrol adalah $\mathrm{p}<0,05$ dan kelompok perlakuan adalah $\mathrm{p}<0,05$. Perbandingan antar kelompok menunjukkan perbedaan yang signifikan $(\mathrm{p}<0,05)$ pada perbedaan skor SF-36 pretest dan posttest dimana kelompok kontrol $(6,32 \pm 3,21)$ dan perlakuan $(23,95 \pm$ $9,75)$.

Diskusi: Skor pre-test SF-36 antar kelompok tidak menunjukkan perbedaan yang signifikan. Sedangkan hasil post-test meningkat secara signifikan pada skor rata-rata SF-36 kedua kelompok. Hal ini mungkin disebabkan oleh walaupun latihan yang dilakukan oleh kedua kelompok berbeda, namun mereka tetap melakukan latihan yang berpengaruh pada persendian. Meskipun demikian, hasil post-test kelompok perlakuan masih mengalami peningkatan yang lebih baik secara signifikan dibandingkan dengan kelompok kontrol.

Kesimpulan: Intervensi prehabilitation exercise dengan resistance band dapat meningkatkan kualitas hidup pasien yang menjalani TKR. Kualitas hidup lebih meningkat pada mereka yang melakukan prehabilitation exercise dibandingkan dengan mereka yang melakukan terapi konvensional.

Kata Kunci: kualitas hidup, prehabilitation exercise, total knee replacement. 
Corresponding details:

\section{Erna Setiawati, MD}

Email: roswithaerna@fk.undip.ac.id

Department of Physical Medicine and

Rehabilitation, Kariadi General Hospital

Faculty of Medicine Diponegoro University, Semarang, Indonesia

\section{INTRODUCTION}

Osteoarthritis (OA) is the most common form of arthritis and a major cause of musculoskeletal pain and disability. ${ }^{1}$ There are some treatment options, conservative and operative. Conservative therapy described as pharmacological treatment to control pain and maintaining functional ability. Operative procedure is chosen when conservative procedure fails. Therapy of choice as operative procedure in OA was total knee replacement (TKR). ${ }^{2}$ Total knee replacement is an operative procedure where knee joint is replaced with a prosthetic joint generally made of metal. ${ }^{3}$

Preoperative muscle strength, functional ability and level of pain are the main predictors of functional performance after TKR. ${ }^{4}$ An exercise program like prehabilitation exercise is expected to contribute in improving outcomes postoperatively. One form of resistance training that can be applied is resistance training using elastic products such as resistance bands. Elastic resistance products in exercise programs have been widely used in rehabilitation and proving to be an effective method of providing enough resistance to increase the muscle strength. The strengthening effect that obtained using resistance bands has the same effect as other modalities such as leg press and pulley.
However that, resistance bands have several advantages such as its portability (easy to carry) and inexpensive so they can be used for home programs, they do not depend on gravity so they can be used for variety of combination patterns of exercise movements on the extremities and body. Futhermore it is safe. ${ }^{5,6}$

Short Form-36 (SF-36) Questionnaire is a form of generic questionnaire that is widely used in studies. This questionnaire consists of 36 questions which are divided into 8 dimensions. These dimensions include; dimensions of physical function, physical role, pain, general health, social function, vitality, the role of emotion, and mental health and will then be grouped into 2 components, the physical component consists of physical function, physical role, pain and general health, while the mental component consists of the role of emotions, vitality, mental health and social functions. ${ }^{7}$

The purpose of this study was to determine the effect of prehabilitation exercise intervention with a resistance band on the quality of life of patients undergoing total knee replacement using SF-36 questionnaire.

\section{METHODS}

This study was a randomized controlled trial pre-test and post-test control group design by comparing the effects of prehabilitation exercise using resistance bands in patients undergoing Total Knee Replacement at the orthopedic clinic, Kutilang Room, Kepodang Installation, and Gymnasium located on ground floor of Murai Installation in Dr. Kariadi General Hospital Semarang on May until September 2019. The total sample was 16 people who were recruited 
using consecutive sampling technique and then simple randomization was carried to divide the subjects into 2 groups.

Inclusion criteria including patients who scheduled for unilateral TKR caused by grade 3-4 knee OA according to Kellgren and Lawrence criteria, patients with Q angle $<14^{\circ}$ as measured by scanogram, patients with a body mass index of 18.5 to $29.9 \mathrm{~kg} / \mathrm{m}^{2}$ (normal to grade 1 obese according to Asia Pacific classification), patients aged 55-75 years, patients with Barthel index > 80 , patients who able to walk with or without walking devices, cooperative and willing to participate in the study by signing informed consent, patients who own a smartphone with Whatsapp application installed (messages and videos call) for monitoring home programs, patients which live in Semarang or its surroundings, and patients who reimbursed by social health provider (BPJS).
Exclusion criteria were patients who scheduled for TKR revision, patients with genu valgus abnormalities, patients with a non-sedentary level of physical activity, patients who having a history of heart disease, malignant hypertension (blood pressure $>180 / 120 \mathrm{mmHg}$ ), history of uncontrolled Diabetes Mellitus ( $>250 \mathrm{mg} / \mathrm{dl}$ ), a history of surgery whether or not related to TKR 3 months before, patients who taking drugs such as Nitrats, digitalis or phenothiazides, patients with MMSE score $<24$, patients muscle strength with MMT $<4$, patients who experiencing pain that could not be tolerated at the time of exercise (Numerical Rating Scale> 5).

The drop out criteria were patients who did not attend the scheduled prehabilitation exercise and post-TKR rehabilitation 2 times in a row or did not come 3 times inconsecutively, and patients who did not show up at initial and final assessment of the study.

Table 1. Prehabilitation exercise component and progression

\begin{tabular}{|c|c|c|c|c|}
\hline Exercise & Week 1 & Week 2 & Week 3 & Week 4 \\
\hline Level of Resistance & \multicolumn{2}{|c|}{ Low Resistance } & \multicolumn{2}{|c|}{ Moderate resistance } \\
\hline Warm up & \multicolumn{4}{|c|}{5 minute, slow walking } \\
\hline \multicolumn{5}{|l|}{ Squat } \\
\hline \multicolumn{5}{|l|}{ Knee curl } \\
\hline \multicolumn{5}{|l|}{ Hip abduction } \\
\hline \multicolumn{5}{|l|}{ Hip adduction } \\
\hline Hip flexion & 1 set $x 10$ repetition & 2 set $\mathrm{x} 10$ repetition & 1 set $x 10$ repetition & 2 set $\mathrm{x} 10$ repetition \\
\hline \multicolumn{5}{|l|}{ Hip extension } \\
\hline \multicolumn{5}{|l|}{$\begin{array}{l}\text { Ankle plantarflexion } \\
\text { (calf raise) }\end{array}$} \\
\hline \multicolumn{5}{|l|}{ Ankle dorsiflexion } \\
\hline $\begin{array}{l}\text { Step-ups (forward and } \\
\text { lateral) }\end{array}$ & $\begin{array}{l}8 \text { steps up and down, } \\
\text { laterally. Stair height } \\
3 \text { inches. }\end{array}$ & $\begin{array}{l}12 \text { steps up and } \\
\text { down, laterally. Stair } \\
\text { height } 5 \text { inches. }\end{array}$ & $\begin{array}{l}16 \text { steps up and } \\
\text { down, laterally. Stair } \\
\text { height } 5 \text { inches. }\end{array}$ & $\begin{array}{l}20 \text { steps up and } \\
\text { down, laterally. Stair } \\
\text { height } 7 \text { inches. }\end{array}$ \\
\hline Cool down & \multicolumn{4}{|c|}{ Stretching, 2 sets $\mathrm{x} 20$ seconds, 5 minutes walking } \\
\hline
\end{tabular}


Exercise given in both group for 4 weeks before surgery. The treatment group was given prehabilitation exercise using resistance band 3 times a week (twice a week in the Gymnasium at Murai Installation of dr. Kariadi General Hospital Semarang and once a week at home). Two levels of resistance band were used, low resistance using red theraband and medium resistance using green theraband.

The components and progression of the exercise are detailed in Table 1. The prehabilitiaion exercise movement on table 1 chosen due to their effect on strengthening the muscles of hip, knee and ankle. In OA patients, not only the muscle in the knee was affected but also the muscles in the hip and ankle, so they need to be strengthened. ${ }^{15}$

All participants in the control group were given conventional therapy as exercise. Conventional therapy given is ergocycle and TENS (Transcutaneous Electrical Nerve Stimulation). Ergocycle is one form of joint exercise. TENS was chosen as modality therapy because it is most commonly used in reducing pain in osteoarthitis. Control group doing this conventional therapy exercise twice a week which has been done in the Gymnasium Room and the ground floor of the Murai Installation of dr. Kariadi General Hospital Semarang.

After TKR operative procedure, both groups received the same medical rehabilitation programs according to Clinical Practice Rehabilitation Practice Post-TKR Kariadi General Hospital Semarang. ${ }^{16}$ Subjects were given exercises starting from the first day after the operation was discharged from the hospital ( $+4-5$ days) in the form of ankle pumping, joint exercises, transfer exercises, and walking exercises using a walker.
Post-test exercise in both groups performed up to 8 weeks after TKR with a frequency of 2 times a week in the form of passive joint scope exercises using Continuous Passive Movement (CPM) and cryotherapy. Respondent's quality of life was measured using the Short-Form-36 (SF36) instrument before the beginning of exercise which was 4 weeks before surgery and the last exercise which was 8 weeks postoperatively.

The data were collected from data collection sheet then coded, tabulated and inputed into computer. Data analysis includes descriptive analysis and hypothesis tests. Before testing the hypothesis, the normality of the distribution of domain data and SF-36 score was carried out using the Shapiro Wilk test. The hypothesis test was carried out using paired $t$ and Wilcoxon test to find out the difference of domain value and SF-36 score before and after treatment in the groups. The value of scores of SF-36 before and after treatment difference between groups were tested using unpaired $t$ and Mann Whitney test. All of the data were computerized and processed using SPSS ${ }^{\circledR}$ software. Significance in this study was obtained if the $p$ value $<0.05$ with $95 \%$ confidence intervals.

Before conducting the research, this study has been passed the ethical clearance test by Ethical Commission of the Faculty of Medicine, Diponegoro University/Dr. Kariadi General Hospital Semarang. The willingness of participants to be included in the study was given by writing (informed consent). The participants were previously explained the objectives, benefits and effects that can occur as a result of research. Participant data will be kept confidential and not published unless with the participant's permission. 

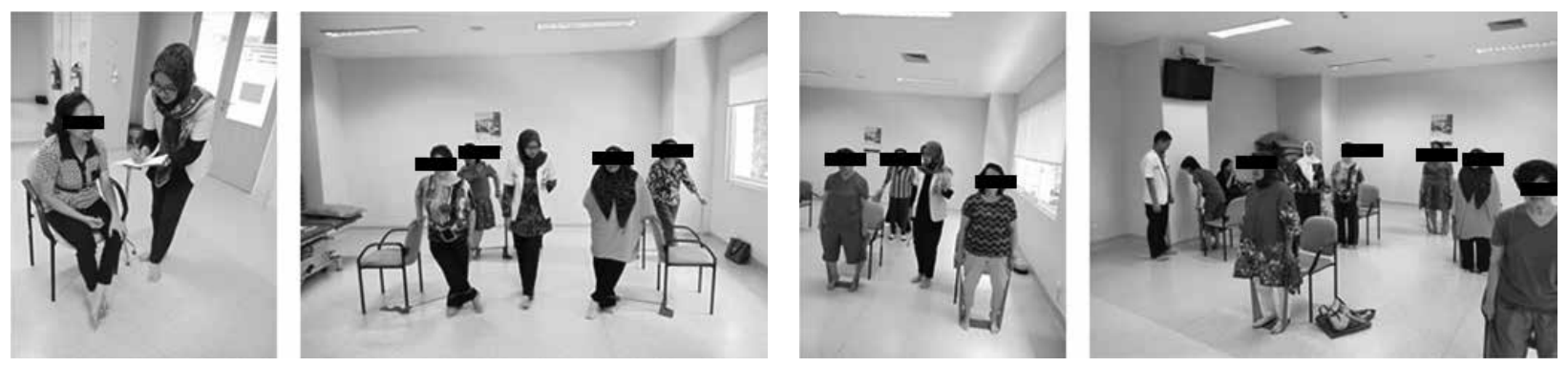

Figure 1. Patients during prehabilitation exercise.

\section{RESULTS}

The number of subjects analyzed in this study was 16 people. There were no dropped out subject. Demographic data or characteristics of participants are described in Table 2. Both groups were homogeneous and there were no significant differences at baseline before the intervention in control and treatment group including sex, age, BMI, pain scale as measured by NRS, ROM flexion, and ROM extension. In this study, all of the participants in both groups are classified as sedentary in the physical activity levels. All participants in this study had an MMSE (Mini Mental State Examination) score of more than 24 (no cognitive impairment)
Quality of life was assessed at 4 weeks before surgery and 8 weeks postoperatively in both groups. In Table 3, we could see the mean baseline value of each SF-36 domains among the subjects between the two groups were not significantly different at the beginning of the study by using the Mann-Whitney test where $p$ $>0.05$. All domains had an increase value in the post-test result. The post-test results of physical functioning domain value significantly better in treatment group than control group (treatment group $66.25 \pm 3.54$, control group $46.25 \pm 13.03$, $\mathrm{p}=0.003$ ), role limitation due to physical health (treatment group $68.75 \pm 11.57$, control group $46.88 \pm 8.84, \mathrm{p}=0.003$ ), energy (treatment group $60.63 \pm 6.23$, control group $47.50 \pm 11.34, \mathrm{p}=$

Table 2. Characteristics of the participants

Variable

\begin{tabular}{lccc}
\multicolumn{1}{c}{ Variable } & Treatment $(\mathrm{n}=8)$ & Control $(\mathrm{n}=8)$ & \\
\hline Gender & & & \\
Male & $0(0 \%)$ & $2(25 \%)$ & $0.467^{*}$ \\
$\quad$ Female & $8(100 \%)$ & $6(75 \%)$ & \\
Age & $67(57-75)$ & $67.5(56-70)$ & $0.916 \dagger$ \\
IMT & $26.04 \pm 3.67$ & $27.02 \pm 2.45$ & $0.540 \dagger$ \\
NRS & $4.25 \pm 1.39$ & $5.50 \pm 1.51$ & $0.107 \dagger$ \\
Flexion ROM & $123.13 \pm 17.72$ & $118.13 \pm 16.24$ & $0.259 \dagger$ \\
Extension ROM & $3.75 \pm 6.94$ & $5.63 \pm 7.29$ & $0.522 \dagger$ \\
\hline
\end{tabular}

*Chi square; †Mann Whitney; †Independent t 
0.005), emotional well-being (treatment group $67.50 \pm 3.34$, control group $58.50 \pm 7.07, \mathrm{p}=$ 0.009 ), social functioning (treatment group 65.63 \pm 12.94 , control group $45.31 \pm 6.47, \mathrm{p}=0.003)$, and general health (treatment group $55.63 \pm 6.23$, control group $49.38 \pm 3.20, p=0.036$ ), while the post-test results of role limitations due to emotional problems and pain domain between the two groups were not significantly different.

Table 4 explained the mean baseline value of SF36 in treatment group with mean of $41.18 \pm 9.40$ and control group with mean $43.78 \pm 5.66$, did not differ significantly with $p>0.05$, while the post-test results of treatment group with a mean of $23.95 \pm$
9.75 were better than the control group $6.32 \pm 3.21$, which was statistically significant with $\mathrm{p}<0.05$

From table 3 and table 5, the difference between the domains value of SF-36 in treatment group at the pre-test and post-test showed a statistically meaningful increase on the entire domains, whereas the control group had significant increase on the energy, emotional well-being, and pain domain.

In table 4 and table 6, shown the mean SF-36 difference values in the treatment group $(23.95 \pm$ 9.75) had increase significantly with $\mathrm{p}<0.05$. The same was also happen in the control group who had a significant increase $(6.32 \pm 3.21)$ with $\mathrm{p}<0.05$.

Table 3. Comparison of mean SF-36 domains value between treatment and control group

\begin{tabular}{|c|c|c|c|c|}
\hline \multirow{2}{*}{ SF-36 Doma } & \multicolumn{4}{|c|}{ Groups } \\
\hline & & Treatment $(\mathrm{n}=8)$ & Control $(\mathrm{n}=8)$ & $\mathrm{p}$ \\
\hline \multirow{3}{*}{$\begin{array}{l}\text { Physical } \\
\text { functioning }\end{array}$} & Pre test & $35.00 \pm 13.89$ & $40.63 \pm 17.20$ & $0.484 \dagger$ \\
\hline & Post test & $66.25 \pm 3.54$ & $46.25 \pm 13.03$ & $0.003 \dagger^{*}$ \\
\hline & Difference & $31.25 \pm 13.30$ & $5.63 \pm 6.78$ & $<0.001 \dagger^{*}$ \\
\hline \multirow{3}{*}{$\begin{array}{l}\text { Role limitation due } \\
\text { to physical health }\end{array}$} & Pre test & $34.38 \pm 12.94$ & $40.63 \pm 12.94$ & $0.333^{\ddagger}$ \\
\hline & Post test & $68.75 \pm 11.57$ & $46.88 \pm 8.84$ & $0.003^{* *}$ \\
\hline & Difference & $34.38 \pm 12.94$ & $6.25 \pm 11.57$ & $0.002+*$ \\
\hline \multirow{3}{*}{$\begin{array}{l}\text { Role limitations due } \\
\text { to emotional problems }\end{array}$} & Pre test & $50.00 \pm 17.85$ & $50.00 \pm 17.85$ & $1.000^{*}$ \\
\hline & Post test & $75.03 \pm 15.41$ & $58.35 \pm 15.46$ & 0.053 \\
\hline & Difference & $25.03 \pm 15.44$ & $8.35 \pm 15.46$ & $0.076^{*}$ \\
\hline \multirow{3}{*}{ Energy } & Pre test & $39.38 \pm 14.25$ & $39.38 \pm 14.25$ & $1.000^{*}$ \\
\hline & Post test & $60.63 \pm 6.23$ & $47.50 \pm 11.34$ & $0.005^{\ddagger *}$ \\
\hline & Difference & $21.25 \pm 13.03$ & $8.13 \pm 9.23$ & $0.027^{\sharp *}$ \\
\hline \multirow{3}{*}{ Emotional well-being } & Pre test & $52.50 \pm 8.12$ & $56.00 \pm 8.28$ & $0.408 \dagger$ \\
\hline & Post test & $67.50 \pm 3.34$ & $58.50 \pm 7.07$ & $0.009 \dagger^{*}$ \\
\hline & Difference & $15.00 \pm 10.64$ & $2.50 \pm 2.07$ & $0.003^{\ddagger *}$ \\
\hline
\end{tabular}


Table 3. Comparison of mean SF-36 domains value between treatment and control group

\begin{tabular}{|c|c|c|c|c|}
\hline & & & & \\
\hline SF-36 D & & Treatment $(\mathrm{n}=8)$ & Control $(\mathrm{n}=8)$ & $\mathrm{p}$ \\
\hline & Pre test & $35.94 \pm 12.39$ & $40.63 \pm 11.08$ & 0.428 \\
\hline Social functioning & Post test & $65.63 \pm 12.94$ & $45.31 \pm 6.47$ & $0.003^{\ddagger *}$ \\
\hline & Difference & $29.69 \pm 17.60$ & $4.69 \pm 6.47$ & $0.006^{\ddagger *}$ \\
\hline & Pre test & $39.06 \pm 12.88$ & $40.31 \pm 13.26$ & $0.851 \dagger$ \\
\hline Pain & Post test & $61.56 \pm 10.26$ & $48.44 \pm 15.06$ & $0.061 \dagger$ \\
\hline & Difference & $22.50 \pm 14.08$ & $8.13 \pm 5.13$ & 0.065 \\
\hline & Pre test & $43.13 \pm 5.30$ & $42.50 \pm 6.55$ & $0.871 \dagger$ \\
\hline General health & Post test & $55.63 \pm 6.23$ & $49.38 \pm 3.20$ & $0.036^{* *}$ \\
\hline & Difference & $12.50 \pm 5.98$ & $6.88 \pm 5.94$ & $0.080^{\S}$ \\
\hline
\end{tabular}

* Significant $(\mathrm{p}<0.05) ; \dagger$ Independent $\mathrm{t}$; Paired $\mathrm{t},{ }^{\ddagger}$ Mann Whitney

Table 4. Comparison of quality of life scores (SF-36) between treatment and control group

\begin{tabular}{lccc}
\hline \multicolumn{1}{c}{ SF-36 } & Groups & \\
& $\begin{array}{c}\text { Treatment }(\mathrm{n}=8) \\
\text { Mean } \pm \text { SD }\end{array}$ & $\begin{array}{c}\text { Control }(\mathrm{n}=8) \\
\text { Mean } \pm \text { SD }\end{array}$ \\
\hline Pre test & $41.18 \pm 9.40$ & $43.78 \pm 5.66$ & $0.516 \dagger$ \\
Post test & $65.14 \pm 5.89$ & $50.08 \pm 3.14$ & $<0.001 \dagger^{*}$ \\
Difference & $23.95 \pm 9.75$ & $6.32 \pm 3.21$ & $0.001 \dagger^{*}$ \\
\hline
\end{tabular}

* Significant $(\mathrm{p}<0.05) ; \uparrow$ Independent $\mathrm{t}$

Table 5. Mean differences of quality of life (SF-36) domain scores in treatment and control group

\begin{tabular}{|c|c|c|}
\hline \multirow[b]{2}{*}{$\Delta$ Domain SF-36 } & \multicolumn{2}{|c|}{ Groups } \\
\hline & $\begin{array}{c}\text { Treatment }(n=8) \\
P\end{array}$ & $\begin{array}{c}\text { Control }(\mathrm{n}=8) \\
\mathrm{P}\end{array}$ \\
\hline Physical functioning & $<0.001 \dagger^{*}$ & $0.051 \%$ \\
\hline Role limitation due to physical health & $0.009^{\| *}$ & $0.157^{\|}$ \\
\hline Role limitations due to emotional problems & $0.016^{\| *}$ & $0.102^{\|}$ \\
\hline Energy & $0.011^{\| *}$ & $0.024 \| *$ \\
\hline Emotional well-being & $0.005+*$ & $0.011 \% *$ \\
\hline Social functioning & $0.017^{\| *}$ & $0.083^{\|}$ \\
\hline Pain & $0.003+*$ & $0.003 t^{*}$ \\
\hline General health & $0.011^{\| *}$ & $0.026^{\|}$ \\
\hline
\end{tabular}

* Significant $(\mathrm{p}<0.05)$; †Independent $\mathrm{t}$; ${ }^{\circledR}$ Paired t, ${ }^{\star}$ Mann Whitney; "Wilcoxon 
Table 6. Mean differences of quality of life (SF-36) scores in treatment and control group

Groups

\begin{tabular}{ccc} 
SF-36 & $\begin{array}{c}\text { Treatment }(\mathrm{n}=8) \\
\mathrm{P}\end{array}$ & $\begin{array}{c}\text { Control }(\mathrm{n}=8) \\
\mathrm{P}\end{array}$ \\
\hline & $<0.001^{\text {** }}$ & $0.001^{\text {ศ* }}$ \\
\hline
\end{tabular}

* Significant $(\mathrm{p}<0.05) ;{ }^{9}$ Paired $\mathrm{t}$

\section{DISCUSSION}

There were no statistically significant differences in participants characteristics including age, sex, BMI, NRS and ROM flexion and extension (Table2) between treatment group and control group ( $\mathrm{p}$ value $>0.05$ ). The conclusion from the data in Table 2 is that the characteristics of the research subjects in the two groups are homogeneous. Subjects in this study were 16 patients who were scheduled unilateral TKR with a cause of grade 3-4 knee OA aged 55-75 years. Subject characteristics showed a mean age of 65.94 years. The subjects in this study consisted of 14 women and 2 men.

In this study, the SF-36 assessment was performed on 16 patients who underwent TKR. They were divided into 2 groups, control group and treatment group. Control group consists of 8 patients received conventional therapy (ergocycle and TENS) and the other group which consists of 8 patients underwent prehabilitation exercise, consisting of strengthening exercise with therabands. In contrast to Swank et al. which gave the treatments to 71 subjects with severe knee osteoarthritis who will undergo TKR and the results showed that the short-term prehabilitation exercise (4-8 weeks) with the resistance exercise as the main component effectively increased leg muscle strength and functional performance of individuals with severe genu osteoarthritis. ${ }^{7}$ Brown et al. study suggested that the duration of the intervention prehabilitation exercise longer than this study is approximately 6-12 weeks followed by a strengthening exercise program more aggressive post-surgery can improve muscle strength is greater beyond the initial capabilities and therefore also increase the functional capacity. ${ }^{8}$

In the comparison of the results of the pre-test and post-test, both groups had a significantly increased mean score for the SF-36 futhermore the post-test results in the treatment group had a significantly better improvement than those of the control group. Increased SF-36 mean score in both groups might be caused by although the exercises performed by the two groups were different, they still did exercises that had an effect on joints. In control group with conventional therapy (ergocycle and TENS) and treatment group with prehabilitation exercise using resistance band which both affect the assessment score of the SF- 36 .

Treatment group post-test results had a significantly better improvement than those of the control group. In the treatment group, they received prehabilitation exercise with a resistance band, resistance exercise that works by increasing the adaptation of nerves 
and the recruitment of motor units to help increase muscle strength. ${ }^{10}$ This result was in accordance with a study held by Keurenties et al. ${ }^{9}$ that reported that prehabilitation exercise was effective in increasing postoperative strength and mobility for patients undergoing TKR also consistent with a cohort study of patients with TKR by Brown et al. showing a significant improvement in the 36 items of SF-36 score postoperatively. ${ }^{8}$ In contrast to the result of this study, a meta-analysis by Jian xiong Ma et al. ${ }^{11}$ where physical function score of SF-36 at 3 month was evaluated in 2 studies including a total of 176 patients, their results indicated that there were no significant differences between the two groups and a systematic review by Sebastiano et al. ${ }^{12}$ showed that prehabilitation exercise for patients undergoing TKR leads to shorter length of stay but not to an enhanced postoperative recovery.

Meanwhile, there are two SF-36 domains that did not significantly different in comparison between the treatment group and control group; pain and role limitations due to emotional problems. This result was in accordance to previous study by Doiron-cadrin et al. ${ }^{13}$ that studied about teleprehabilitation and in-person prehabilitation on TKR candidate patients, though it resulted to an improved physical performance, especially for walking speed or stair performance for patients with hip or knee OA after TKR, it didn't decrease pain. A study to OA patients underwent TKR by Levinger et al. ${ }^{14}$ resulted mental health component of SF- 36 deteriorated in the first 6 months following the surgery, with improvement demonstrated at 12 months post-surgery, and they stated that psychological factors influence patients' postsurgical outcomes, including persistent pain, reduced level of function, and overall satisfaction with the procedure. While the causes for the reduction in mental health early after the operation are unclear, assessment of mental health is important to better identify patients who are at risk of poor outcome post- operatively.

This study has several limitations. Both groups had a significant increase in post-test results even though the treatment group score were higher but the differences in post-test results were less visible. It may be necessary in choosing a more suitable control group exercise in order to get better result score.

We did not further analyze the direct effect of prehabilitation exercise on muscle strength, pain, ROM and wound healing processes that can affect functional performance which then affect quality of life.

\section{CONCLUSION}

Prehabilitation exercise intervention using resistance bands improving the quality of life of patients undergoing TKR. The quality of life improving more in those who do prehabilitation exercise than those who do conventional therapy.

\section{REFERENCES}

1. Alshami AM. Knee osteoarthritis related pain: a narrative review of diagnosis and treatment. Int J Heal Sci Qassim Univ. 2014;(8(1).

2. Guccione AA, Wong RA, Avers A, Editors. Geriatric physical therapy. 3rd Ed. St. Louis Missouri: Elsevier Mosby; 2012.

3. Hochberg M, Altman R, April K. American college of rheumatology 2012 recommendations for the use of 
nonpharmacologic and pharmacologic therapies in osteoarthritis of the hand, hip and knee. Arthritis Care Pes;2012;64(4):465-74

4. Kay C, Prapavessis H, Doherty T. The effect of a prehabilitation exercise program on quadriceps strength for patients undergoing total knee arthroplasty: a randomized controlled pilot study. PM R. 2012;4(9):64756.

5. McKay C, Prapavessis H, Doherty T. The effect of a prehabilitation exercise on quadriceps strenght for patients undergoing total knee arthroplasty: a randomized controlled pilot study. Am Acad Phys Med Rehabil. 2012; 4:647-56.

6. Rausch Osthoff AK, Niedermann K, Braun J, Adams J, Brodin N, Dagfinrud H, et al. 2018 EULAR recommendations for physical activity in people with inflammatory arthritis and osteoarthritis. Annals of the Rheumatic Diseases. 2018;77(1):1251-60.

7. Swank AM, Kachelman JB, Bibeau W. Prehabilitation before total knee arthroplasty increases strength and function in older adults with severe osteoarthritis. J Strength Cond Res. 2011;25(2):318-25.

8. Brown K, Swank A, Quesada P, Nyland J, Malkani A, R T. Prehabilitation versus usual care before total knee arthroplasthy : A case report comparing outcomes within the same individual. Physiother Theory Pract. 2010;399-407.

9. Keurentjes JC, Fiocco M, So-Osman C, Et al. Patients with severe radiographic osteoarthritis have a better prognosis in physical functioning after hip and knee replacement: a cohort-study. PLoS One. 2013; 8:e59500.
10. Valdes AM, Stocks J. Osteoarthritis and ageing. Eur Med J.2018;3(1):116-23.

11. Ma J xiong, Zhang L kai, Kuang $M$ jie, Zhao J, Wang Y, Lu B, et al. The effect of preoperative training on functional recovery in patients undergoing total knee arthroplasty: A systematic review and meta-analysis. Int $\mathbf{J}$ of Surg. 2018;51:205-12

12. Vasta S, Papalia R, Torre G, Vorini F, Papalia G, Zampogna B, et al. The Influence of Preoperative Physical Activity on Postoperative Outcomes of Knee and Hip Arthroplasty Surgery in the Elderly: A Systematic Review. J Clin Med. 2020 ; 9(4):969-75

13. Doiron-Cadrin P, Kairy D, Vendittoli PA, Lowry V, Poitras S, Desmeules F. Feasibility and preliminary effects of a tele-prehabilitation program and an in-person prehablitation program compared to usual care for total hip or knee arthroplasty candidates: a pilot randomized controlled trial. Disabil Rehabil. 2020;42(7):989-98.

14. Levinger $P$, Bartlett JR, Bergman NR, McMahon S, Menz HB, Hill KD. The discrepancy between patient expectations and actual outcome reduces at the first 6 months following total knee replacement surgery. Knee Surgery, Sport Traumatol Arthrosc. 2019;27(7):2042-50.

15. Topp R, Page P. Improve function before knee replacement surgery. Functional U Exercise and activity for healthy aging. 2009; 7(2) : $1-8$

16. Panduan Praktek Klinis Rehabilitasi Medik Pasca Total Knee Replacement. Semarang: RS Kariadi : 2018 